\title{
Vadelman lepotilan purkaminen lämminvesikäsittelyn avulla
}

\author{
Pauliina Palonen \\ Soveltavan biologian laitos, PL 27,00014 Helsingin yliopisto, pauliina.palonen@helsinki.fi
}

\begin{abstract}
Johdanto
Suomen oloissa vadelman lepotila (endodormanssi) on ohi jo tammikuussa (Palonen ja Lindén 1999). Yleisesti uskotaan, että talvivauriot syntyvät keväällä, kun vadelma lepotilan heikkenemisen myötä menettää kylmänkestävyyttään ja karaistumiskykyään. Tutkimustulokset lepotilan vaikutuksesta vadelman kylmänkestävyyteen ovat kuitenkin ristiriitaisia. Tämä johtuu ainakin osaksi koejärjestelyistä, joista on vaikea poistaa muita vaikuttavia tekijöitä, kuten vuodenaikaa tai lämpötilaa. Monien puuvartisten kasvien silmulepo voidaan purkaa kuumavesikäsittelyllä (esim. Orffer ja Goussard 1980, Wang ja Faust 1994, Wisniewski ym. 1997). Mikäli käsittely toimii myös vadelmalla, olisi mahdollista tutkia lepotilan ja kylmänkestävyyden suhdetta ilman vuodenajan ja muiden häiritsevien tekijöiden vaikutusta.

Tämän kokeen tavoitteena oli kehittää menetelmä vadelman lepotilan purkamiseksi keinotekoisesti sekä tutkia levonpurkukäsittelyn vaikutusta kylmänkestävyyteen. Menetelmää käyttäen voitaisiin jatkossa selvittää lepotilan suhdetta kylmänkestävyyteen, kestävyyden purkautumisherkkyyteen sekä uudelleenkaraistumiskykyyn.
\end{abstract}

\section{Aineisto ja menetelmät \\ Levonpurkukäsittelyt}

Erilaisten lämminvesikäsittelyjen tehoa vadelman silmulevon purkamisessa tutkittiin neljällä vadelmalajikkeella. Maurin Makea-, Muskoka- ja Ottawa-lajikkeita kerättiin MTT:n Hämeen tutkimusasemalta ja Preussen-lajiketta kenttäkokeesta Viikistä 9. marraskuuta 1998. Näytteet säilytettiin yön yli kylmiössä $\left(0^{\circ} \mathrm{C}\right)$. Kustakin lajikkeesta 36 versoa jaettiin satunnaisesti kuuteen vesihaudekäsittelyyn: 1) kontrolli, 2) $20^{\circ} \mathrm{C}$ vesi, 3) $35^{\circ} \mathrm{C}$ vesi, 4) $40^{\circ} \mathrm{C}$ vesi, 5) $45^{\circ} \mathrm{C}$ vesi ja 6) $50^{\circ} \mathrm{C}$ vesi. Yksi verso muodosti aina toiston, joten kokeessa oli kuusi toistoa. Verson viisi ylintä silmua ja tyvi poistettiin siten, että versoon jäi 15 silmua. Näytteet laitettiin vesihauteeseen 2 h:n ajaksi käsittelynmukaiseen lämpötilaan, paitsi kontrollinäytteet, jotka pidettiin käsittelyjen ajan kylmiössä $\left(0^{\circ} \mathrm{C}\right)$.

Levonpurkukäsittelyn jälkeen mitattiin lepotilan syvyys. Näytteet paloiteltiin yhden silmun sisältäviksi pätkiksi, ja laitettiin perliittiin tuettuina hyötöön sumupetiin kasvihuoneeseen $\left(20^{\circ} \mathrm{C}\right.$, valojakso $16 \mathrm{~h}$, suhteellinen kosteus $95 \%$ ). Puhjenneiden silmujen määrä laskettiin joka kolmas päivä kuuden viikon ajan. Lepotilan syvyyttä kuvaamaan laskettiin logit-malleja käyttäen (Lindén ym. 1996) $\mathrm{DD}_{50}$-arvo (dormant days ${ }_{50}$ ); aika, jossa puolet silmuista puhkeaa hyödössä. Käsittelyjen ja lajikkeen vaikutusta lepotilan syvyyteen testattiin kaksisuuntaisella varianssianalyysillä. Keskiarvojen parivertailut tehtiin Tukeyn testillä.

\section{Levonpurkukäsittelyn vaikutus kylmänkestävyyteen}

Koe levonpurkukäsittelyn vaikutuksesta kylmänkestävyyteen tehtiin talven 1999-2000 aikana neljästi: 19. lokakuuta, 22. marraskuuta, 5. tammikuuta ja 29. helmikuuta. Levonpurkukäsittelyksi valittiin edellisen vuoden kokeen perusteella $45^{\circ} \mathrm{C}$ vesi, ja lajikkeeksi 'Ottawa', koska sen vaste käsittelyihin oli selkein. Vadelmanversoja kerättiin Viikistä, ja ne käsiteltiin jälleen niin, että kuhunkin jäi 16 silmua. Puolet versoista (D) alistettiin lepotilanpurkukäsittelyyn $\left(45^{\circ} \mathrm{C}\right.$ vesi, $\left.2 \mathrm{~h}\right)$ ja puolet olivat käsittelemättömiä kontrolleja (C). Käsittelyn jälkeen mitattiin lepotilan syvyys ja kylmänkestävyys. Kylmätestiin sekä lepotilan mittaukseen käytettiin yhteensä neljä versoa käsittelyä ja toistoa kohti. Toistoja oli neljä.

Lepotilan syvyys $\left(\mathrm{DD}_{50}\right)$ mitattiin kunkin verson kahdeksasta ylimmästä näytesilmusta (yhteensä 32 silmua / käsittely / toisto) kasvihuoneessa hyödössä, kuten yllä on kuvattu. Kylmätestien avulla mitattiin levonpurkukäsittelyn vaikutus silmujen ja versojen kylmänkestävyyteen. Yksisilmuiset versonpalat (verson kahdeksan alinta näytesilmua) laitettiin muovipusseissa pakastuskaappiin (Weiss 2600/45...5 Du-Pi, Weiss Umwelttechnik, Reiskirchen, Saksa). Kaapin lämpötilaa laskettiin $5 \mathrm{~K} / \mathrm{h}$, ja pidettiin 30 min testilämpötiloissa. Seitsemän testilämpötilaa olivat viiden asteen välein ja testikerrasta riippuen välillä $-5^{\circ} \ldots-40^{\circ} \mathrm{C}$. Kussakin testilämpötilassa otettiin ulos neljä silmua käsittelyä ja toistoa kohti. 
Näytteiden annettiin sulaa $0^{\circ} \mathrm{C}: s s a$, minkä jälkeen niitä säilytettiin huoneenlämmössä. Kylmäkäsittelyn aiheuttamat vauriot mitattiin noin 10 vuorokauden kuluttua silmävaraisesti stereomikroskoopin avulla havainnoimalla erikseen silmujen ja versojen elävyyttä. Kylmänkestävyyden kuvaamiseksi tuloksista laskettiin LT $_{50}$-lämpötilat käyttämällä logit-malleja (Lindén ym. 1996). Käsittelyn vaikutusta lepotilan syvyyteen ja kylmänkestävyyteen testattiin yksisuuntaisella varianssianalyysillä.

\section{Tulokset}

\section{Levonpurkukäsittelyt}

Lepotilan syvyyteen vaikutti levonpurkukäsittelyn $(\mathrm{p}<0,001)$ lisäksi lajike $(\mathrm{p}<0,001)$. Näiden kahden tekijän välillä oli myös yhdysvaikutus $(\mathrm{p}<0,001)$, jonka vuoksi parivertailut tehtiin lajikekohtaisesti. Maurin Makea -lajikkeella lepo purkautui tehokkaimmin $40^{\circ} \mathrm{C}$ vesikäsittelyllä, vaikkakaan se ei tilastollisesti eronnut muista käsittelylämpötiloista (Taulukko 1). Muilla lajikkeilla 45-asteinen vesi oli tehokkain levon purkamisessa, mutta ainoastaan 'Ottawalla' se erosi merkitsevästi muista käsittelylämpötiloista. Kaikki näytteet kuolivat $50^{\circ} \mathrm{C}: n$ käsittelyssä. Käsittelemättömissä näytteissä syvin lepo oli Maurin Makea- ja Preussen-lajikkeilla ja heikoin lepo Muskoka- ja Ottawa-lajikkeilla. Hyödön aikana puhjenneiden silmujen osuus eri käsittelyissä vaihteli välillä 4,4 ja 95,3 \% (Taulukko 2).

Taulukko 1. Lepotilan syvyys $\left(\mathrm{DD}_{50}\right)$ neljällä vadelmalajikkeella 9. marraskuuta ja erilaisten levonpurkukäsittelyjen jälkeen. Kullakin lajikkeella erikseen, samalla kirjaimella merkityt arvot eivät eroa merkitsevästi $(\mathbf{p}<0,05)$ Tukeyn testissä.

\begin{tabular}{llllll}
\hline Lajike & $\mathrm{DD}_{50}(\mathrm{~d})$ & & & & \\
\cline { 2 - 6 } & Kontrolli & $20^{\circ}$ vesi & $35^{\circ} \mathrm{C}$ vesi & $40^{\circ} \mathrm{C}$ vesi & $45^{\circ} \mathrm{C}$ vesi \\
\hline Maurin Makea & $49,6 \mathrm{a}$ & $45,4 \mathrm{ab}$ & $42,1 \mathrm{ab}$ & $37,5 \mathrm{~b}$ & $42,5 \mathrm{ab}$ \\
Muskoka & $38,5 \mathrm{ab}$ & $54,1 \mathrm{a}$ & $42,6 \mathrm{ab}$ & $40,7 \mathrm{ab}$ & $27,8 \mathrm{~b}$ \\
Ottawa & $31,8 \mathrm{~b}$ & $56,9 \mathrm{a}$ & $34,3 \mathrm{~b}$ & $29,6 \mathrm{~b}$ & $16,6 \mathrm{c}$ \\
Preussen & $45,9 \mathrm{a}$ & $49,9 \mathrm{a}$ & $36,3 \mathrm{~b}$ & $26,7 \mathrm{c}$ & $24,4 \mathrm{c}$ \\
\hline
\end{tabular}

Taulukko 2. Levonpurkukäsittelyjen vaikutus kuuden viikon hyödön aikana puhjenneiden silmujen osuuteen $(\%)$ neljällä vadelmalajikkeella.

\begin{tabular}{|c|c|c|c|c|c|}
\hline \multirow[t]{2}{*}{ Lajike } & \multicolumn{5}{|c|}{ Puhkeamis -\% } \\
\hline & Kontrolli & $20^{\circ}$ vesi & $35^{\circ} \mathrm{C}$ vesi & $40^{\circ} \mathrm{C}$ vesi & $45^{\circ} \mathrm{C}$ vesi \\
\hline Maurin Makea & 12,1 & 35,5 & 40,0 & 62,0 & 36,0 \\
\hline Muskoka & 57,3 & 15,6 & 41,8 & 46,2 & 76,7 \\
\hline Ottawa & 79,1 & 4,4 & 58,0 & 72,0 & 95,3 \\
\hline Preussen & 23,9 & 13,6 & 62,2 & 93,8 & 88,6 \\
\hline
\end{tabular}

\section{Levonpurkukäsittelyn vaikutus kylmänkestävyyteen}

Talven 1999-2000 aikana levonpurkukäsittelyn $\left(45^{\circ} \mathrm{C}, 2 \mathrm{~h}\right)$ vaikutus lepotilan syvyyteen sekä versojen ja silmujen kylmänkestävyyteen vaihteli eri näytteenottoaikoina (Taulukko 3). Käsittelyn vaikutus lepotilan syvyyteen oli merkitsevä $(\mathrm{p}<0,05)$ kaikilla muilla näytteenottokerroilla paitsi 5. tammikuuta. Käsittely pienensi $\mathrm{DD}_{50}$-arvoa lokakuussa $17,2 \mathrm{~d}$ ja marraskuussa 2,2 d. Helmikuussa se viivästytti silmujen puhkeamista; $\mathrm{DD}_{50}$-arvo kasvoi 5,3 d. Levonpurkukäsittely heikensi versojen ja silmujen kylmänkestävyyttä kaikilla näytteenottokerroilla ( $\mathrm{p}<0,001)$. Silmujen kylmänkestävyys heikkeni eri näytteenottokerroilla $9,1-13,4^{\circ} \mathrm{C}$ ja versojen kestävyys $8,4-14,6^{\circ} \mathrm{C}$. Lämminvesikäsitellyissä näytteissä kylmätestin aiheuttama vaurio ilmeni silmun tyven johtojänteiden solukon selvärajaisena ruskettumisena. Vastaavaa ei havaittu kylmätestissä vaurioituneissa kontrollinäytteissä, joissa tyvi oli tasaisemmin ruskettunut tai kukka-aiheet näkyvästi vaurioituneet. 
Taulukko 3. Levonpurkukäsittelyn (D) $\left(45^{\circ} \mathrm{C}, 2 \mathrm{~h}\right)$ vaikutus 'Ottawa'-vadelman lepotilan syvyyteen $\left(\mathrm{DD}_{50}\right)$ sekä versojen ja silmujen kylmänkestävyyteen $\left(\mathbf{L T}_{50}\right)$ eri näytteenottoaikoina. $\mathrm{C}=$ kontrollinäytteet. Keskiarvon jäljessä sulkeissa keskivirhe.

\begin{tabular}{lllll}
\hline Näytteenottoaika & Käsittely & $\mathrm{DD}_{50}(\mathrm{~d})$ & $\mathrm{LT}_{50}$ versot $\left({ }^{\circ} \mathrm{C}\right)$ & $\mathrm{LT}_{50}$ silmut $\left({ }^{\circ} \mathrm{C}\right)$ \\
\hline 19.10. & $\mathrm{C}$ & $29,5(2,0)$ & $-23,3(0,9)$ & $-21,9(1,3)$ \\
22.11. & $\mathrm{D}$ & $12,3(2,4)$ & $-14,9(0,1)$ & $-12,5(0)$ \\
& $\mathrm{C}$ & $11,0(0,2)$ & $-34,4(2,5)$ & $-27,5(1,9)$ \\
5.1. & $\mathrm{D}$ & $8,8(1,2)$ & $-19,8(0,7)$ & $-15,1(0,1)$ \\
& $\mathrm{C}$ & $10,8(1,6)$ & $-30,7(0,7)$ & $-28,7(1,3)$ \\
29.2. & $\mathrm{D}$ & $13,3(1,8)$ & $-21,6(0,6)$ & $-15,3(0,6)$ \\
& $\mathrm{C}$ & $5,4(0,4)$ & $-32,2(2,5)$ & $-27,5(0)$ \\
& $\mathrm{D}$ & $10,7(0,6)$ & $-21,6(2,4)$ & $-18,4(2,5)$ \\
\hline
\end{tabular}

\section{Tulosten tarkastelu}

Yleensä $5^{\circ} \mathrm{C}$ :n lämpötilan ajatellaan olevan kaikkein tehokkain levon purkamisessa (Fuchigami ja Nee 1987). Myös erilaisten subletaalien stressien, joko kemiallisten tai korkean tai alhaisen lämpötilan aiheuttamien, on todettu purkavan puuvartisten kasvien lepoa (Tanino ym. 1989, Fuchigami ja Nee 1987, Wang ja Faust 1994, Shirazi ja Fuchigami 1995). Tähän liittyviä fysiologisia tai biokemiallisia reaktioita ei tunneta. Tiedetään kuitenkin, että subletaali stressi lisää solukon etyleenintuotantoa ja ionien vuotoa solukalvojen läpi (Wisniewski ym. 1996). Vadelman silmulevon purkamisessa 45asteinen vesi oli tehokkain, vaikka vaste vaihtelikin eri lajikkeilla. Yleisimmin lepotilan purkamiseen on käytetty käsittelyitä $40^{\circ}-47^{\circ} \mathrm{C}: \mathrm{ssa}$, ja kosteuden on todettu tehostavan korkean lämpötilan vaikutusta (Wisniewski ym. 1996). 'Muskokalla' ja 'Ottawalla' 20-asteinen vesikäsittely syvensi lepoa niin, että se melkein kokonaan esti silmujen puhkeamisen; 'Ottawalla' vain $4 \%$ ja 'Muskokalla' $16 \%$ silmuista puhkesi. Tämä saattoi johtua nk. vilutuksen negaatiosta. Lyhytkestoinen kohtalaisen korkea lämpötila saattaa aiheuttaa vilutuksen negaation ja pidentää tai syventää endodormanssia (Weinberger 1967, Erez ym. 1979).

Fuchigami ym. (1982) kehittivät puuvartisten kasvien vuosisykliä kuvaamaan mallin (degree growth stage model), jossa vuosi jaetaan 360 asteeseen $\left({ }^{\circ} \mathrm{GS}\right)$. Silmulepo (endodormanssi) alkaa $180^{\circ} \mathrm{GS}: n$ kohdalla ja on syvimmillään $270^{\circ} \mathrm{GS}: n$ kohdalla. Lepo ohenee 270 ja $315^{\circ} \mathrm{GS}: n$ välillä ja on täysin purkautunut $315^{\circ} \mathrm{GS}: s s a ̈ . ~ 315$ ja $360^{\circ} \mathrm{GS}: n$ välillä silmut ovat ekodormanssissa. Lepoa purkavat käsittelyt ovat tehokkaimpia endodormanssin varhaisessa $\left(180-200^{\circ} \mathrm{GS}\right)$ ja myöhäisessä $\left(300-315^{\circ} \mathrm{GS}\right)$ vaiheessa, ja vähemmän tehokkaita syvimmän levon aikana (200-300 ${ }^{\circ} \mathrm{GS}$ ) (Siller-Cepeda ym. 1992, Wisniewski ym. 1994, 1996). Fuchigamin ja Neen (1987) mukaan syanamidikäsittely $\left(\mathrm{CH}_{2} \mathrm{~N}_{2}, 0,25-\right.$ $1,25 \mathrm{M}$ ) purki omenapuun (Malus sylvestris L.) ja lännenkanukan (Cornus sericea L.) levon $180 \mathrm{ja}$ $310^{\circ} \mathrm{GS}: n$ välillä, mutta ekodormanssin aikana $\left(315-360^{\circ} \mathrm{GS}\right)$ se esti tai viivästytti silmujen puhkeamista. Wisniewskin ym. (1994) mukaan myös lämpökäsittely on tehoton tai viivästyttää silmujen puhkeamista ekodormanssin myöhäisessä vaiheessa $\left(330-360^{\circ} \mathrm{GS}\right)$. Meidän tuloksemme vahvistavat osaltaan aikaisempia havaintoja. Vadelmansilmut olivat oletettavasti syvimmässä levossa (lähellä $\left.270^{\circ} \mathrm{GS}\right) 19$. lokakuuta, jolloin $\mathrm{DD}_{50}$ oli noin $30 \mathrm{~d}$ ja lämminvesikäsittely lyhensi silmujen puhkeamiseen kuluvaa aikaa noin $17 \mathrm{~d}$. Marraskuun loppupuolella $\mathrm{DD}_{50}$ oli enää $11 \mathrm{~d}$ ja lämminvesikäsittelyn jälkeen noin $9 \mathrm{~d}$. Koska tammikuun alussa lämminvesikäsittelyllä ei ollut vaikutusta lepoon, tämä oli ilmeisesti käännekohta endodormanssin ja ekodormanssin välillä $\left(315^{\circ} \mathrm{GS}\right)$. Myös aiemmissa tutkimuksissa vadelman endodormanssin on todettu olevan purkautunut tammikuuhun mennessä (Jennings ym. 1972, Måge 1975, Palonen ja Lindén 1999). Helmikuun lopussa lämminvesikäsittely viivästytti silmujen puhkeamista noin $5 \mathrm{~d}$, joten silmut oletettavasti olivat ekodormanssissa $\left(315-360^{\circ} \mathrm{GS}\right)$.

Yleensä lepoa purkava subletaali stressi myös vähentää silmujen kylmänkestävyyttä (Tanino ym. 1989, Wisniewski ym. 1994). Samankaltainen stressikäsittely sekä purkaa levon että poistaa silmuista jään kiteytymisen esteen, joka on edellytyksenä niiden alijäähtymiselle (Wisniewski ym. 1996). Vadelmansilmujen kylmänkestävyys heikkeni levonpurkukäsittelyn seurauksena $9,1-13,4^{\circ} \mathrm{C}$, ja eniten silloin, kun kestävyys oli suurimmillaan. Vadelmalla versojenkin kylmänkestävyys heikkeni $8,4-14,6^{\circ} \mathrm{C}$, vaikka kirjallisuudessa on tietoja, joiden mukaan levonpurkukäsittely ei vaikuttaisi versojen kylmänkestävyyteen (Shirazi ja Fuchigami 1995). Vadelman kylmänkestävyys heikkeni myös ekodormanssin aikana, jolloin lämminvesikäsittely ei enää purkanut lepoa, joten näyttää siltä, että 
kylmänkestävyyden heikkeneminen ei ollut yhteydessä lepotilan purkautumiseen, vaan että korkea käsittelylämpötila itsessään purki kestävyyttä, vaikka sen kesto oli vain kaksi tuntia.

\section{Johtopäätökset}

Vadelman lepotilassa taitekohta endodormanssin ja ekodormanssin välillä on ilmeisesti tammikuun alussa. Sen jälkeen kasvu voisi suotuisissa oloissa alkaa, ja vain epäsuotuisat ympäristöolot pitävät lepoa yllä. Vadelman endodormanssi saadaan puretuksi kokeessa testatulla $45^{\circ} \mathrm{C}: n$ vesikäsittelyllä. Käsittely vähensi versojen ja silmujen kylmänkestävyyttä. Tosin näin tapahtui niilläkin mittauskerroilla ekodormanssin aikana, jolloin lämminvesikäsittely ei enää purkanut lepoa. Käsittelyn kylmänkestävyyttä heikentävä vaikutus johtuikin todennäköisesti korkeasta käsittelylämpötilasta, joka itsessään purki kylmänkestävyyttä, eikä niinkään lepotilan purkautumisesta. Kokeen tavoitteena oli kehittää menetelmä, jolla kylmänkestävyyden ja lepotilan yhteyttä voidaan tutkia ilman muita häiritseviä tekijöitä, mutta tätä tavoitetta ei muuten mielenkiintoisista tuloksista huolimatta saavutettu. Jatkossa kannattaisi tutkia kemikaalien (gibberelliini, syanamidi) sopivuutta vadelman lepotilan purkamiseen.

\section{Kirjallisuus:}

Erez, A., Couvillon, G.A. \& Hendershott, C.H. 1979. The effect of cycle length on chilling negation by high temperature in dormant peach leaf buds. J. Amer. Soc. Hort. Sci. 104: 573-576.

Fuchigami, L.H. \& Nee, C.-C. 1987. Degree growth stage model and rest-breaking mechanisms in temperate woody perennials. Hortscience 22: 836-845.

Fuchigami, L.H., Weiser, C.J., Kobayashi, K., Timmis, R. \& Gusta, L.V. 1982. A degree growth stage ( $\left.{ }^{\circ} \mathrm{GS}\right)$ model and cold acclimation in temperate woody plants. Teoksessa: Li, P.H. \& Sakai, A. (toim.) Plant Cold Hardiness and Freezing Stress, Vol. 2. Academic Press, New York. s. 93-116.

Jennings, D.L., Carmichael, E. \& Costin, J.J. 1972. Variation in the time of acclimation of raspberry canes in Scotland and Ireland and its significance for hardiness. Horticultural Research 12: 187-200.

Lindén, L., Rita, H. \& Suojala, T. 1996. Logit models for estimating lethal temperatures in apple. Hortscience 31: 91-93.

Måge, F. 1975. Dormancy in buds of red raspberries. Meldingar fra Norges Landbrukshögskole vol. 54, no. 21. $24 \mathrm{~s}$.

Orffer, C.J. \& Goussard, P.G. 1980. Effect of hot water treatments on bud burst and rooting of grapevine cuttings. Vitis 19: 1-3.

Palonen, P. \& Lindén, L. 1999. Dormnacy, cold hardiness, dehardening and rehardening in selected red raspberry cultivars. J. Amer. Soc. Hort. Sci. 104: 573-576.

Shirazi, A.M. \& Fuchigami, L.H. 1995. Effects of "near-lethal" stress on bud dormancy and stem cold hardiness in red-osier dogwood. Tree Physiol. 15: 275-279.

Siller-Cepeda, J.H., Fuchigami, L.H. \& Chen, T.H.H. 1992. Glutathione content in peach buds in relation to development and release of rest. Plant Cell Physiol. 33: 867-872.

Tanino, K.K., Fuchigami, L.H., Chen, T.H.H., Gusta, L.V. \& Weiser, C.J. 1989. Dormancy-breaking agents on acclimation and deacclimation of dogwood. Hortscience 24: 353-354.

Wang, S.Y. \& Faust, M. 1994. Changes in the antioxidant system associated with budbreak in 'Anna' apple (Malus domestica Borkh.) buds. J. Amer. Soc. Hort. Sci. 119: 735-741.

Weinberger, J.H. 1967. Some temperature relations in natural breaking of the rest of peach flower buds in San Joaquin Valley, California. Proc. Amer. Soc. Hort. Sci. 91: 84-89.

Wisniewski, M., Fuchigami, L.H., Sauter, J.J., Shirazi, A. \& Zhen, L. 1996. Near-lethal stress and bud dormancy in woody plants. Teoksessa: Lang, G.A. (toim.) Plant dormancy: Physiology, biochemistry and molecular biology. CAB International, Oxon, UK. s. 201-210.

Wisniewski, M., Sauter, J., Fuchigami, L. \& Stepien, V. 1997. Effects of near-lethal heat stress on bud break, heat-shock proteins and ubiquitin in dormant poplar (Populus nigra Charkowiensis $\times$ P. nigra incrassata). Tree Physiol. 17: 453-460.

Wisniewski, M., Sauter, J., Stepien, V. \& Fuchigami, L. 1994. Effects of sublethal heat stress on endodormancy and ecodormancy of peach and hybrid poplar. (Abstr.). Hortscience 29: 511. 